\title{
Capital Inflows and Economic Growth: An Indian Perspective
}

\author{
Sharad Nath Bhattacharya \\ Army Institute of Management, Kolkata
}

\author{
Mousumi Bhattacharya \\ Army Institute of Management, Kolkata
}

\begin{abstract}
The paper investigates the possible cointegration and the direction of causality between various components of capital inflows and economic growth in India. A cointegration test is performed in a vector autoregression (VAR) framework followed by an application of a Vector-Error Correction Model (VECM), Granger Causality test and Impulse response analysis. Bi-directional causality is observed between foreign direct investment (FDI) and economic growth, external assistance and economic growth, external assistance and other capital. Unidirectional causality is observed from foreign portfolio investment (FPI) and other capital to economic growth, and from economic growth to NRI (Non- Resident Indians) deposit.
\end{abstract}

Keywords: capital inflows, GDP, VECM, Multivariate Granger-causality

JEL Classification: F21, F43, O1

\section{Sermaye Girişi ve Ekonomik Büyüme: Hindistan Örneği Özet}

Bu çalışma, Hindistan'daki sermaye girişinin çeşitli bileşenleri ile ülkedeki ekonomik büyüme arasındaki olası eş-bütünleşmeyi ve nedenselliğin yönünü incelemektedir. $\mathrm{Bu}$ doğrultuda vektör otoregresyon (VAR) modeli çerçevesinde eş-bütünleşme testi ile Vektör Hata Düzeltme Modeli (VECM), Granger nedensellik testi ve etki-tepki analizi uygulanmıştır. Analizler sonucunda, doğrudan yabancı yatırımlar (FDI) ile ekonomik büyüme; dış yardım ile ekonomik büyüme ve dış yardım ile diğer sermaye girişleri arasında çift yönlü nedensellik ilişkileri bulunmuştur. Bunların dışında, yabancı portfolyo yatırımları (FPI) ve diğer sermaye girişlerinden ekonomik büyümeye ve ekonomik büyümeden yerleşik olmayan yatırımcıların mevduatları büyüklüğüne doğru tek yönlü nedensellik ilişkileri gözlemlenmiştir.

Anahtar kelimeler: sermaye girişleri, GSYIH, Çok değişkenlik Granger nedenselliği

\footnotetext{
* Sharad Nath Bhattacharya is an Assistant Professor in the Army Institute of Management, Judges Court Road, Alipore, Kolkata-700027, West Bengal, India. E-mail: sharadbhattacharya@gmail.com

** Mousumi Bhattacharya in an Assistant Professor in the Army Institute of Management, Judges Court Road, Alipore, Kolkata-700027, West Bengal, India. E-mail: mbhattacharya9@gmail.com
} 
I $n$ the New Economic Policy (NEP) of 1990-91 that was announced by the Government of India, one of the objectives was opening the capital account so that capital flows into the country would contribute to exports and output growth. The flow of foreign capital into India gained momentum with the initiation of the new economic policy. The acceleration took place especially in the portfolio flows, although India has received foreign capital in the form of FDI and other forms for a long time. The external sector development in India has been marked by strong capital flows since the 1990s and has gradually gained momentum with the initiation of the economic reforms. There has been a compositional shift from predominantly social and private debt flows to non-debt creating flows in the post-reform period. The capital flows are generally beneficial to an economy although a large surge in capital inflows in a short span of time in excess of the domestic absorptive capacity can be source of stress on the economy. It may give rise to upward pressures on the exchange rate resulting in overheating the economy and leading to possible asset pricing bubbles. India has one of the highest net capital flows among the emerging market economies (EMEs) of Asia. The size of the net capital flows to India increased from as low as US\$ 7.1 billion in 1990-91 to US\$ 45.8 billion in 2006-07 and then to US $\$ 108$ billion during 2007-08, the year before the crisis. It dropped as low as US\$ 7 billion in 2008-09 at the height of the crisis.

After independence in 1947, the economic policies of the Indian government during the first four decades were characterized by planning, control and regulation. India's development strategy was focused on self reliance and import substitutions until the 1980s. Attempts were made at market oriented reforms following the balance of payment pressure which induced policy responses that combined exchange rate depreciation and an easing of restrictions on foreign capital inflows. However such measures were narrow in scope and had little impact on actual inflows which remained very small. The situation changed dramatically with the onset of the reform programs introduced in the early 1990s and the aftermath of the balance of payment crisis of 1991. The three main phases as far as India's approach towards capital flows is concerned are, first, that India's dependence on external flows was mainly restricted to multilateral and bilateral concessional finance during this first phase of capital flows which began at the time of independence and went up to the early 1980s. In the second phase during the 1980s with the widening of the current account deficit, India had recourse to external commercial borrowing including short-term borrowings and deposits from Non Resident Indians (NRI). This resulted in an increase in the proportion of short-term debt in India's total external debt in the late 1980s. In the third phase there was the balance of payment crisis followed by the initiation of a reform process. The approach towards external capital flows was based on the recommendations made in the report of the High Level Committee (Chairman: C. Rangarajan) on the BOP crisis. The objectives of the reform in the external sector were conditioned by the need to correct the deficiencies that led to the payment imbalances in 1991.

Capital flows in the Indian context can be categorized under three broad heads: (a) non-debt creating flows, (b) debt creating flows and (c) other capital. Equity flows under foreign direct investment (FDI) and foreign portfolio investment (FPI) constitute the 
major forms of non-debt creating capital flows into India. External assistance, external commercial borrowings (ECBs), trade credits and a non-repatriable component of NRI deposits constitute the major portion of the external debt in India. Rupee debt service is also a component of debt-creating flows and includes debt owed to Russia as denominated in rupees and converted at current exchange rates, payable in exports. Other capital mainly includes leads and lags in exports (the difference between the custom and the banking channel data), Indian investment abroad and India's subscription to an international institution and its quota. External assistance consists of external aid flows from bilateral and multilateral sources. External Commercial Borrowing (ECB) refers to commercial loans accessed by companies from non-resident lenders in the form of bank loans, buyers' credit, suppliers' credit and securitized instruments (e.g. floating rate notes and fixed rate bonds). ECBs are permitted by the government as an additional source of financing for expanding the existing capacity as well as for fresh investments. The recourse to external commercial borrowings by Indian corporations from international capital markets, although initiated in the early 1970s, remained modest due to the dominance of concessional, non-market based finance in the form of external assistance from bilateral sources and multilateral agencies. After the advent of globalization, capital flows have become particularly prominent, leading to widespread implementation of the liberalization program and financial reforms in various countries across the globe in the 1990s. This resulted in an integration of global financial markets. In India the capital flows and economic growth seem to be positively related to each other as a high surge of capital flows influences the domestic saving, investment and productivity of the country. It also has led to the development of the financial markets as vehicles for the transfer of technology and management skills. The impact of international capital flows on economic growth during the post liberalization period significantly affected the argument over whether capital flows influence growth or growth influence capital flows.

The purpose of this paper is to investigate the possible cointegration and direction of causality between various components of capital inflows and economic growth in India.

\section{Review of the Literature}

There are no models or theories designed exclusively to explain the impact of capital inflows on economic growth because most studies linking capital inflows to growth expand on the existing theories of growth. The growth theories are divided into two schools of thought, one being the exogenous theory of growth or the neoclassical model, the other being the endogenous theory of growth also known as the new theory of growth.

According to the neoclassical growth model, capital inflow in the form of FDI could exert a leveling effect on output per capita because of augmented investment, but not on the growth rate of output (Solow, 1992). In the neoclassical models the thrust for economic growth had to come from outside the system, mainly from technological progress. In the new growth theory of Lucas (1988) and Romer (1990) the key assumption was a belief in the operation of increasing returns made possible by sustained increase in capital 
invested in both human and physical capital. This in turn would create a permanent increase in the growth rate of an economy. The new growth theory gave importance to innovation in technology as an explanatory factor in the growth rate of an economy (Grossman and Helpman, 1991). It viewed economic growth from the point of view of creative destruction; i.e. the introduction of new technology would help countries climb up in the quality ladders of technology which in turn would lead to a higher growth rate of the economy. Another important argument put forward by Aghion and Howitt (1998), and Howitt, (2000) in their endogenous theory of growth was the effect of technology 'spillovers' on economic growth which they saw as the result of technological progress that could translate into a higher growth rate of the economy. Among the proponents of the endogenous growth theory, Romer and Rivera (1990) believed that as capital flows involved an exchange of ideas, they would help countries bridge the 'idea gap' in the developing countries. Transfer of technology through FDI flows could impact the R \& $\mathrm{D}$ of developing countries in that they could stimulate innovation thereby enhancing growth in the host country (Grossman and Helpman, 1991). A positive relationship between capital inflows and economic growth in different developing countries through enhanced investment was reported in the studies of Bosworth and Collins (1999) and the World Bank (2001). There are reports which reflect a positive relationship between FDI and economic growth in countries with a high absorptive capacity, especially the absorptive capacity of its human capital (Blomstrom et al., 1992; and Borenstein et al., 1998). The empirical evidence of the impact of remittances on economic growth appears to be mixed. Faini (2002) finds a positive relationship between growth and remittances using cross-country data. However, Spatafora (2005) finds that there is no direct link between real per capita output growth and remittances. Chami et al, (2003), using panel data for 113 developing countries, find that remittances have a negative effect on economic growth. A negative relationship between external debt and economic growth has been observed by Krugman (1988) and Hameed et al. (2008). There are also some studies that have reported no relationship between aggregate capital flows and growth (Gounder and Xayaong, 2001; Carkovic and Levine, 2002).

There are hardly any studies about India related to debt creating and non-debt creating capital flow and economic growth using decomposed capital flow data. Related empirical studies in an Indian context have concentrated on capital flows in India and their impact on domestic macro variables since the beginning of the 2000s. Rangrajan (2000) investigated the capital flows and their impact on the capital formation and economic growth, taking into account the variables as net private capital flows, net direct investment, net official flows, net portfolio investment and other net investments in 22 countries from 1992 to 2000. According to Duttaray et al. (2003) capital flows can contribute to the growth rate of the host economy by augmenting the capital as well as by an infusion of technology, given that the high growth rates would lead to a better investment climate by enhancing more capital flows in the country. Therefore the capital growth relationship is a subject of causality with a possibility of a two-way relationship. According to Kohli $(2001,2003)$ portfolio flows are rendering the financial markets more volatile through increased linkage between the domestic and foreign financial 
markets. Mazumdar (2005) did not find any evidence in favor of capital flows that led to economic growth in India; he also concluded that capital inflows have not had much impact on India's export growth or productivity. A number of empirical studies do not find evidence that greater openness and higher capital flows have led to higher growth (e.g Prasad et al., 2007). D'Souza (2008) noted that the difference between the capital flows into India as compared with other EMEs are that (a) they are associated with a deteriorating current account position rather than an improving one, and (b) the extent of financial outflows has only partially offset the capital inflows. The author also notes that capital flows in India have been associated with a buoyant stock market and a rise in investment and interest rates in the economy. Studies by Pradhan (2010) and Ray (2012) used only a single component of capital flow, viz. FDI and observed bi- directional causality between FDI and growth for India.

Overall, the empirical literature yields a complex and mixed picture about the relationship between capital flows and growth. The capital inflows are found to affect economic growth mostly in the short run, and the strong long-run relationship between growth and capital inflows are limited in empirical studies. There are a few possible explanations for the limited presence of long-run relationships. Bussiere and Fratzscher, (2008) observed that growth rate for developing economies from financial liberalization are higher as an immediate aftermath of liberalization, but not later, and that investment is positively related to growth only in the years immediately after liberalization, but is not significantly related to growth in the medium to long term. They also concluded that after liberalization, while portfolio flows have a more significant impact on growth in the short run than in the long run, FDI inflows are of benefit only in the medium to long run but not in the short run. Also the effect of portfolio investment on growth is much stronger than the effect of FDI in the short-term post liberalization. These arguments indicate a presence of a boom-bust cycle due to liberalization, as implied by the theoretical models of McKinnon and Pill $(1997,1999)$. They argued that there is a strong intertemporal trade-off from liberalization in that a boom in investment and portfolio inflows raises growth immediately after liberalization, but such benefit disappears in the medium to long run.

\section{Data and Methodology}

\section{Data}

Quarterly data (1996-97:Q1 to 2008-09:Q4) covering a period of 13 years have been obtained from the Reserve Bank of India (RBI) annual reports and the Handbook of Statistics of Indian Economy, published by RBI. GDP at the 1999-2000 market prices is used to measure economic growth. The components of capital inflows considered for the purpose of the study include non-debt creating inflows [Foreign Direct Investment (FDI) and Foreign Portfolio Investment (FPI)], debt-creating flows [External Assistance (EXTASS), External Commercial Borrowing (EXTCOMM), NRI deposits (NRIDEP)] and Other Capital inflows (OTHERCAP) in the Balance of Payment (Capital Account). 
Figure 1

Logarithmic values of FDI, FPI, GDP, EXTASS, EXTCOMM, NRIDEP and OTHERCAP ( $X$ and $Y$ axis represents time period [1996-97: Quarter 1 to 2008-09: Quarter 4] and values respectively)

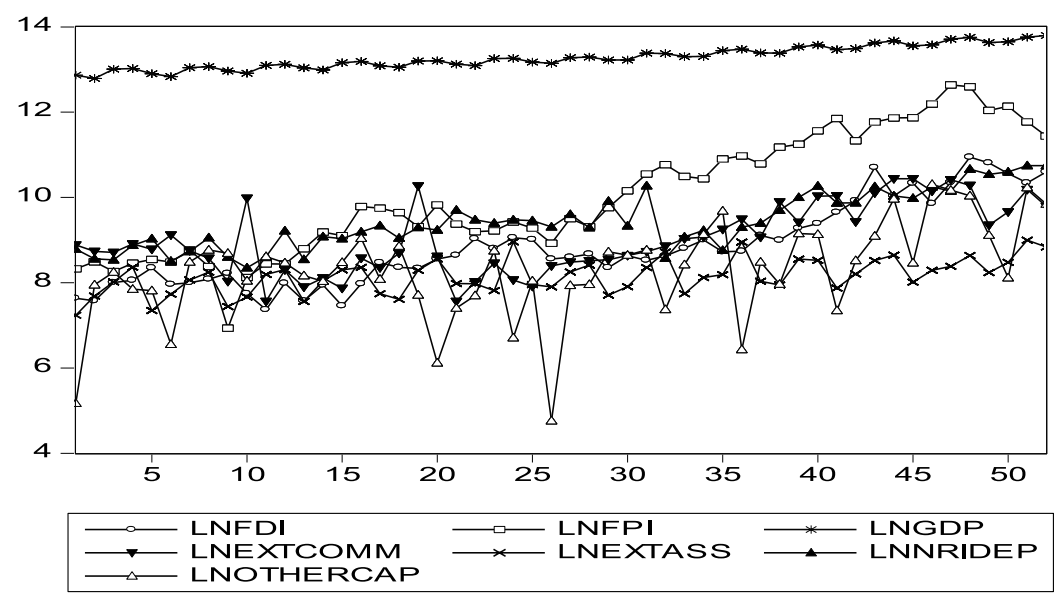

\section{Methodology}

The study has used the Granger-Causality Test in a multivariate Vector Autoregressive (VAR) framework to examine the causal links between FDI, FPI, EXTASS, EXTCOMM, OTHERCAP, NRIDEP and GDP over the period 1996-97:Q1 to 2008-09:Q4.

\section{Tests for Stationarity}

The first step in the methodology is to test the stationarity of the variables. Augmented Dickey Fuller (ADF) [1979], Phillips-Perron (PP) [1988] and Kwiatkowski, Phillips, Schmidt and Shin (KPSS) [1992] tests have been conducted to investigate the stationarity property of the series.

\section{Tests for Cointegration}

After examining the stationarity of the variables involved in the study, an attempt is made to figure out the level of cointegration between the examined variables, i.e., those tied in a long-run relationship. A Cointegration Test is conducted to determine the long-run economic relationship between the variables (Thomas, 1993). In this study, the Error-correction Cointegration technique of Johansen (1988) and Johansen and Juselius (1990) has been applied to identify the cointegration relationship between the variables. Johansen and Juselius' (1990) approach to the number of co-integrating vectors is applicable only if all the variables are I(1). The Cointegration Test of maximum likelihood (based on the Johansen-Juselius Test) has been developed based on a VAR approach initiated by Johansen (1988). A p-dimensional VAR model, involving up to k-lags, can be specified as below: 


$$
Z_{t}=\prod_{1} Z_{t-1}+\prod_{2} Z_{t-2}+\ldots \ldots \ldots . \prod_{k} Z_{t-k}+\varepsilon_{t}
$$

where $Z_{t}$ is a $(p \times 1)$ vector of $\mathrm{p}$ potential endogenous variables and each of the $\Pi_{t}$ is a $(p \times p)$ matrix of parameters and $\varepsilon_{t}$ is the white noise term. Equation (1) can be formulated into an Error Correction Model (ECM) form as below:

$$
\Delta Z_{t}=\prod_{k} Z_{t-k}+\sum_{i=1}^{k-1} \theta_{i} \Delta Z_{t-i}+\varepsilon_{t}
$$

where $\Delta$ is the first difference operator, $\Pi$ and $\theta$ are $\mathrm{p}$ by p matrices of unknown parameters and $\mathrm{k}$ is the order of the VAR translated into a lag of $(\mathrm{k}-1)$ in the ECM and $\varepsilon_{t}$ is the white noise term. Evidence of the existence of cointegration is the same as evidence of the rank (r) for the In matrix. Johansen and Juselius (1990) have shown that the rank of $r$ of $\Pi$ in equation (2) is equal to the number of co-integrating vectors in the system. When the rank of $\Pi$ is reduced, i.e. $[1 \leq \operatorname{Rank} \Pi \leq(p-1)]$, even if all the variables are individually I(1), the level-based long-run component would be stationary. In this case, there are $(\mathrm{p}-1)$ cointegrating vectors. The appropriate modelling methodology here is the Vector-Error Correction Model (VECM). Johansen and Juselius (1990) have developed two Likelihood Ratio Tests. The first test is the Likelihood Ratio Test based on the maximal Eigen value which evaluates the null hypothesis of ' $r$ ' cointegrating vector(s) against the alternative of ' $r+1$ ' cointegrating vectors. The second test is the Likelihood Ratio Test based on the Trace Test which evaluates the null hypothesis of, at most, ' $r$ ' cointegrating vector(s) against the alternative hypothesis of more than ' $r$ ' cointegrating vectors. If the two variables are I(1), but cointegrated, the Granger Causality Test will be applied in the framework of ECM in which long-run components of the variables obey equilibrium constraints while the short-run components have a flexible dynamic specification.

\section{Test for Granger Causality with VECM}

In order to examine the causal linkages between the variables, the Granger Causality Test has been conducted. The direction of the impact of each of the variables is also determined from the analysis. In order to capture the impact of variables observed in the past time period in explaining the future performance, the optimal lag length $\mathrm{p}$ (which is 3 in the present study) is chosen (Table 1) and the criteria used in selecting the VAR model and optimal lag length require the combination of information criterion (minimum of AIC or SBIC or HQIC or FPE value). The above selection criteria would guarantee that neither too short a lag length is chosen to result in serially correlated errors nor too many lags are included that might induce specification bias for having inefficient parameters (Hendry and Mizon, 1993). 
Table 1

VAR Lag Order Selection (D.LnFDI, D.LnFPI, D.LnGDP, D.LnEXTCOMM, D.LnEXTASS, D.LnNRIDEP, D.LnOTHERCAP)

\begin{tabular}{l|l|l|l|l|l|l}
\hline Lag & LL & LR & FPE & AIC & SIC & HQIC \\
\hline 0 & -160.3309 & NA & $2.52 \mathrm{E}-06$ & 6.972122 & $7.245005^{*}$ & 7.075245 \\
\hline 1 & -78.2958 & 136.7252 & $6.49 \mathrm{E}-07$ & 5.595659 & 7.778727 & 6.420643 \\
\hline 2 & 15.65491 & 129.1822 & $1.14 \mathrm{E}-07$ & 3.722712 & 7.815964 & $5.269558^{*}$ \\
\hline 3 & 80.34664 & $70.08271^{*}$ & $8.50 \mathrm{e}-08^{*}$ & $3.068890^{*}$ & 9.072326 & 5.337597 \\
\hline
\end{tabular}

* indicates lag order selected by the criterion.

If the variables contain a cointegrating vector, causality exists in at least one direction. According to Engle and Granger (1987), if two series, say X and Y, are integrated of order one [i.e., I(1)] and cointegrated, then there is a possibility of a causal relationship in at least one direction. The direction of a causal relationship can be detected in the VECM. Engel and Granger (1987) have found that, in the presence of cointegration, there always exists a corresponding error-correction representation, captured by the errorcorrection term (ECT). This means that changes in the dependent variable are a function of the level of disequilibrium in the cointegrating relationship as well as changes in the other explanatory variable(s). The ECT captures the long-run adjustment of cointegration variables. As such, in addition to the direction of causality, the incorporation of ECT in the VECM allows a detection of both short- and long-run causal relationships between the variables. On the other hand, if no cointegrating vector exists in the model, the standard VAR should be applied to test the causal relationship between variables. As a prerequisite of causality testing, it is necessary to check the cointegrating properties of the variables, and then, in order to examine the causal linkages, VECM is specified, which can be expressed as follows:

$$
\begin{aligned}
& \Delta L n F D I_{t}=\sum_{j=1}^{p-1} \beta_{11, j} \Delta L n F D I_{t-j}+\sum_{j=1}^{p-1} \beta_{12, j} \Delta L n F P I_{t-j}+\sum_{j=1}^{p-1} \beta_{13, j} \Delta L n G D P_{t-j}+\sum_{j=1}^{p-1} \beta_{14, j} \Delta L n E X T A S S_{t-j}+
\end{aligned}
$$

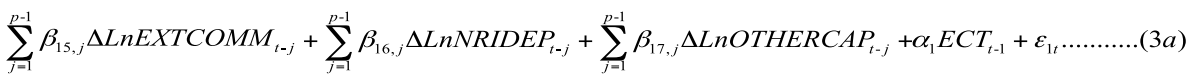

$$
\begin{aligned}
& \Delta L n F P I_{t}=\sum_{j=1}^{p-1} \beta_{21, j} \Delta L n F P I_{t-j}+\sum_{j=1}^{p-1} \beta_{22, j} \Delta L n F D I_{t-j}+\sum_{j=1}^{p-1} \beta_{23, j} \Delta G D P_{t-j}+\sum_{j=1}^{p-1} \beta_{24, j} \Delta L n E X T A S S_{t-j}+
\end{aligned}
$$

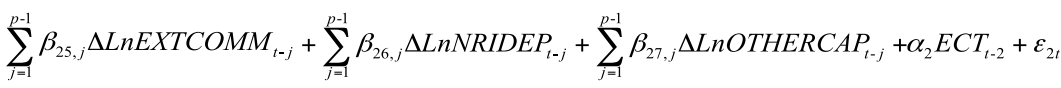

$$
\begin{aligned}
& \Delta L n G D P_{t}=\sum_{j=1}^{p-1} \beta_{31, j} \Delta L n G D P_{t-j}+\sum_{j=1}^{p-1} \beta_{32, j} \Delta L n F D I_{t-j}+\sum_{j=1}^{p-1} \beta_{33, j} \Delta L n F P I_{t-j}+\sum_{j=1}^{p-1} \beta_{34, j} \Delta L n E X T A S S_{t-j}+
\end{aligned}
$$

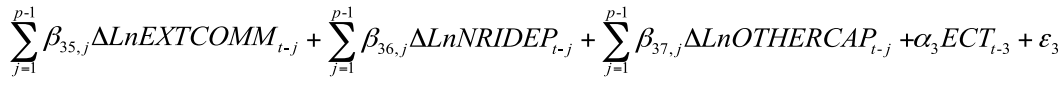




$$
\begin{aligned}
& \Delta L n E X T C O M M_{t}=\sum_{j=1}^{p-1} \beta_{41, j} \Delta L n E X T C O M M_{t-j}+\sum_{j=1}^{p-1} \beta_{42, j} \Delta L n F D I_{t-j}+\sum_{j=1}^{p-1} \beta_{43, j} \Delta F P I_{t-j}+\sum_{j=1}^{p-1} \beta_{44, j} \Delta L n G D P_{t-j}+ \\
& \left.\sum_{j=1}^{p-1} \beta_{45, j} \Delta L n E X T A S S_{t-j}+\sum_{j=1}^{p-1} \beta_{46, j} \Delta L n N R I D E P_{t-j}+\sum_{j=1}^{p-1} \beta_{47, j} \Delta L n O T H E R C A P_{t-j}+\alpha_{4} E C T_{t-4}+\varepsilon_{4 t} \ldots \ldots \ldots \ldots \ldots . . . \ldots \ldots d\right) \\
& \Delta L n E X T A S S_{t}=\sum_{j=1}^{p-1} \beta_{51, j} \Delta L n E X T A S S_{t-j}+\sum_{j=1}^{p-1} \beta_{52, j} \Delta L n F D I_{t-j}+\sum_{j=1}^{p-1} \beta_{53, j} \Delta L n F P I_{t-j}+\sum_{j=1}^{p-1} \beta_{54, j} \Delta L n G D P_{t-j}+ \\
& \sum_{j=1}^{p-1} \beta_{55, j} \Delta L n E X T C O M M_{t-j}+\sum_{j=1}^{p-1} \beta_{56, j} \Delta L n N R I D E P_{t-j}+\sum_{j=1}^{p-1} \beta_{57, j} \Delta L n O T H E R C A P_{t-j}+\alpha_{5} E C T_{t-5}+\varepsilon_{5 t} \ldots \ldots \ldots . .(3 e) \\
& \Delta L n N R I D E P_{t}=\sum_{j=1}^{p-1} \beta_{61, j} \Delta L n N R I D E P_{t-j}+\sum_{j=1}^{p-1} \beta_{62, j} \Delta L n F D I_{t-j}+\sum_{j=1}^{p-1} \beta_{63, j} \Delta L n F P I_{t-j}+\sum_{j=1}^{p-1} \beta_{64, j} \Delta L n G D P_{t-j}+ \\
& \sum_{j=1}^{p-1} \beta_{65, j} \Delta L n E X T C O M M_{t-j}+\sum_{j=1}^{p-1} \beta_{66, j} \Delta L n E X T A S S_{t-j}+\sum_{j=1}^{p-1} \beta_{67, j} \Delta L n O T H E R C A P_{t-j}+\alpha_{6} E C T_{t-6}+\varepsilon_{6 t} \ldots \ldots \ldots .(3 f) \\
& \Delta L n O T H E R C A P_{t}=\sum_{j=1}^{p-1} \beta_{71, j} \Delta L n O T H E R C A P_{t-j}+\sum_{j=1}^{p-1} \beta_{72, j} \Delta L n F D I_{t-j}+\sum_{j=1}^{p-1} \beta_{73, j} \Delta L n F P I_{t-j}+\sum_{j=1}^{p-1} \beta_{74, j} \Delta L n G D P_{t-j}+ \\
& \sum_{j=1}^{p-1} \beta_{75, j} \Delta L n E X T C O M M_{t-j}+\sum_{j=1}^{p-1} \beta_{76, j} \Delta L n E X T A S S_{t-j}+\sum_{j=1}^{p-1} \beta_{77, j} \Delta L n N R I D E P_{t-j}+\alpha_{7} E C T_{t-7}+\varepsilon_{7 t} \ldots \ldots \ldots \ldots(3 g)
\end{aligned}
$$

where $\Delta$ is the first difference operator and $\varepsilon_{1 t}, \varepsilon_{2 t}, \varepsilon_{3 t}, \varepsilon_{4 t}, \varepsilon_{5 t}, \varepsilon_{6 t}$ and $\varepsilon_{n t}$ are white noise. ECT is the error correction term, and $\mathrm{p}$ is the order of the VAR, which is translated to lag of p-1 in the ECM. $\alpha_{1}, \alpha_{2}, \alpha_{3}, \alpha_{4}, \alpha_{5}, \alpha_{6}$ and $\alpha_{7}$ represent the speed of adjustment after the FDI, FPI, GDP, EXTCOMM, EXTASS, NRIDEP, OTHERCAP deviate from the long-run equilibrium in period $\mathrm{t}-1$.

\section{Impulse Response Analysis}

Impulse responses are the changes in the predicted future values due to a change in the current period values. Typically in a VAR, the coefficient estimates of the individual equations are of little or no importance. Instead of a static interpretation of the effects of changes in any of the variables in the system, Impulse Responses (IR) provide a dynamic response curve that depicts the effects of a change in one of the variables, considering the effects of the other variables in the system. In the present study, the orthogonalized IR analysis is done by changing the order of the equations to see whether any change in the IR function is revealed.

\section{Findings and Discussion}

\section{Stationarity of the Variables}

Table 2 reports the results of the ADF, PP and KPSS Tests of unit root by lag length chosen based on minimum values of SIC. The variables LnFDI, LnFPI, LnGDP, LnNRIDEP and LnEXTCOMM are I(1) processes according to ADF, PP and KPSS tests. The variables LnEXTASS and LnOTHERCAP are I(1) processes according to ADF and KPSS tests but are $\mathrm{I}(0)$ processes according to PP test. 
Table 2

Test of Unit Root Test Hypothesis (1996-97: Q1 - 2008-09: Q4) without Trend

\begin{tabular}{l|l|l|l}
\hline Series & ADF & PP & KPSS \\
\hline LnFDI & I (1) & I (1) & I (1) \\
\hline LnFPI & I (1) & I (1) & I (1) \\
\hline LnGDP & I (1) & I (1) & I (1) \\
\hline LnEXTASS & I (1) & I (0) & I (1) \\
\hline LnNRIDEP & I (1) & I (1) & I (1) \\
\hline LnOTHERCAP & I (1) & I (0) & I (1) \\
\hline LnEXTCOMM & I (1) & I (1) & I (1) \\
\hline
\end{tabular}

\section{Johansen Cointegration Test}

This test confirms the existence of a long-run equilibrium relationship between the variables. The long-run equilibrium relationship means the variables move together over time so that short-term disturbances from the long term trend will be corrected. An absence of cointegration will indicate that such variables have no long run equilibrium relationship, and in principle, they can wander arbitrarily far away from each other (Dickey et al., 1991).

Johansen Cointegration Test results for the cointegration rank $r$ have been presented in Table 3. As per the results of the ADF Test and the KPSS Test, it is observed that the variables have the same order of integration, i.e., I(1). Therefore the Johansen Cointegration Test has been employed to find the cointegration rank and the number of cointegrating vectors. The null hypothesis is rejected in the cases of both the Trace statistic and Max-Eigen value statistic. Table 3 shows that the number of statistically significant cointegration vectors is equal to 3 for both the Trace statistic and Max-Eigen value statistic. The results suggest that there is a long-run relationship among the variables considered for the study.

Table 3

Johansen - Juselius Cointegration Test Results [no deterministic trend (restricted constant)]

\begin{tabular}{l|l|l|l|l}
\hline $\mathbf{H}_{\mathbf{0}}$ & $\mathbf{H}_{\mathbf{1}}$ & $\lambda_{\text {trace }}$ & $C V_{(\text {trace, } 5 \%)}$ & Prob $^{* *}$ \\
\hline$r=0$ & $r \geq 1$ & 288.4315 & 134.6780 & $0.0000^{* *}$ \\
\hline$r \leq 1$ & $r \geq 2$ & 159.7394 & 103.8473 & $0.0000^{* *}$ \\
\hline$r \leq 2$ & $r \geq 3$ & 79.34396 & 76.97277 & $0.0326^{* *}$ \\
\hline$r \leq 3$ & $r \geq 4$ & 38.87878 & 54.07904 & 0.5273 \\
\hline$r \leq 5$ & $r \geq 5$ & 22.11835 & 35.19275 & 0.5875 \\
\hline$r \leq 6$ & $r \geq 6$ & 10.33384 & 20.26184 & 0.6070 \\
\hline
\end{tabular}




\begin{tabular}{l|l|l|l|l}
\hline $\mathrm{H}_{0}$ & $\mathrm{H}_{1}$ & $\lambda_{\max }$ & $C V_{(\max , 5 \%)}$ & Prob** \\
\hline$r=0$ & $r=1$ & 128.6920 & 47.07897 & $0.0000^{* *}$ \\
\hline$r \leq 1$ & $r=2$ & 80.39548 & 40.95680 & $0.0000^{* *}$ \\
\hline$r \leq 2$ & $r=3$ & 40.46518 & 34.80587 & $0.0095^{* *}$ \\
\hline$r \leq 3$ & $r=4$ & 16.76043 & 28.58808 & 0.6808 \\
\hline$r \leq 4$ & $r=5$ & 11.78451 & 22.29962 & 0.6758 \\
\hline$r \leq 6$ & $r=6$ & 5.957541 & 15.89210 & 0.7927 \\
\hline
\end{tabular}

(a) $r$ is the number of cointegrating vectors.

(b) Trace test indicates 3 cointegrating equations at 0.05 level.

(c) Max-eigenvalue test indicates 3 cointegrating equations at 0.05 level.

(d) $* *$ denotes rejection of the null hypothesis at $5 \%$ level of significance.

(e) The critical values (i.e., CVs) are taken from Mackinnon-Haug-Michelis (1999).

\section{Analysis of VECM}

Johansen's $\lambda_{\max }$ and $\lambda_{\text {race }}$ statistics (as per Table 3 ) reveal that the variables under study stand in a long-run relationship among them, thus justifying the use of ECM for showing short-run dynamics. The Granger Representation Theorem (Engle and Granger, 1987) states that, if a set of variables is cointegrated, then a valid error correction representation of the data exists. Under VECM, the significant coefficients of the explanatory variables denote short-term but statistically significant coefficients of the error term ECT that points towards a long-run relationship.

In Table 4 below, the cointegrating equations are given along with the equation for changes in FDI (first column), changes in FPI (second column), changes in GDP (third column), changes in EXTCOMM (fourth column), changes in EXTASS (fifth column), changes in NRIDEP (sixth column), and changes in OTHERCAP (seventh column). The coefficients of ECT contain information about whether the past values affect the current values of the variable under study. A significant coefficient implies that past equilibrium errors play a role in determining the current outcomes. The information obtained from the ECM is related to the speed of adjustment of the system towards long-run equilibrium. The adjustment coefficient on $E C T_{t-3}$ in equation 3(c) is negative and statistically significant (at $1 \%$ level), which means that the error term contributes to explaining changes in GDP, and that a long-term relationship exists between the independent variables and GDP. The long-run relationship has already been established by the cointegration test. The short-run dynamics are captured through the individual coefficients of the difference terms. The difference terms being significant at accepted levels of significance indicates that higher levels of FDI, FPI, EXTASS, OTHERCAP and NRIDEP have a positive impact on GDP in the short run while EXTCOMM has a negative impact on GDP in the short run. GDP also has an impact on NRIDEP. 
Table 4

Summary of Vector Error Correction Estimates

\begin{tabular}{|c|c|c|c|c|c|c|c|}
\hline \multirow{2}{*}{$\begin{array}{c}\text { Independent } \\
\text { Variables }\end{array}$} & \multicolumn{7}{|c|}{ Dependent Variables } \\
\hline & D(LnFDI) & D(LnFPI) & D(LnGDP) & $\begin{array}{l}\text { D } \\
\text { (LnEXT } \\
\text { COMM })\end{array}$ & $\begin{array}{l}\text { D } \\
\text { (LnEX- } \\
\text { TASS) }\end{array}$ & $\begin{array}{l}\text { D(LnNRI } \\
\text { DEP) }\end{array}$ & $\begin{array}{l}\text { D(LnOTHER } \\
\text { CAP) }\end{array}$ \\
\hline ECT & 0.0071 & -0.0149 & $-0.0101 * * *$ & 0.0099 & -0.0087 & $-0.041^{* * *}$ & -0.0428 \\
\hline D(LnFDI $(-1))$ & -0.2644 & -0.1687 & $0.0324 * * *$ & -0.0368 & -0.0705 & 0.3893 & 0.4062 \\
\hline D(LnFDI(-2)) & 0.0140 & -0.3506 & $0.0153^{*}$ & 0.0232 & 0.1451 & -0.0297 & $-1.0127 *$ \\
\hline D(LnFDI $(-3))$ & 0.0044 & -0.3014 & 0.0016 & 0.4759 & 0.1205 & -0.0489 & -0.4251 \\
\hline D(LnFPI(-1)) & 0.0771 & -0.2560 & $0.0253^{* * *}$ & $-0.4214 *$ & 0.0406 & 0.0561 & 0.2178 \\
\hline D(LnFPI(-2)) & 0.2145 & -0.2338 & $0.0205^{* * *}$ & 0.2440 & -0.0560 & -0.0135 & -0.3757 \\
\hline D(LnFPI(-3)) & 0.1258 & 0.2751 & 0.0125 & $0.4808 *$ & -0.0931 & -0.2029 & 0.5497 \\
\hline D(LnGDP(-1)) & $3.7406^{*}$ & 1.4143 & $-1.1796^{* * *}$ & 2.1641 & 1.9047 & -3.4082 & -1.8152 \\
\hline D(LnGDP(-2)) & 1.0578 & -2.6559 & $-1.2189 * * *$ & -2.3851 & -0.7594 & $-4.4467 *$ & -3.3608 \\
\hline D(LnGDP(-3)) & -0.0331 & 2.6090 & $-0.9440 * * *$ & 2.0670 & -0.5494 & $-4.9708 * *$ & -1.4986 \\
\hline D(LnEXTCOMM(-1)) & -0.0811 & 0.0731 & $-0.0095^{*}$ & $-0.4766^{* *}$ & -0.0484 & -0.1357 & $-0.6105^{*}$ \\
\hline D(LnEXTCOMM(-2)) & 0.1041 & 0.1590 & -0.0087 & -0.1642 & -0.0691 & 0.1872 & 0.0573 \\
\hline D(LnEXTCOMM(-3)) & 0.0045 & 0.1278 & -0.0040 & -0.0320 & 0.0193 & 0.0546 & -0.3480 \\
\hline D(LnEXTASS(-1)) & -0.1390 & 0.2375 & $0.0533 * * *$ & 0.0983 & -1.0568 & 0.2822 & 0.8214 \\
\hline D(LnEXTASS(-2)) & -0.1740 & 0.1344 & $0.0326^{*}$ & 0.1880 & -0.7722 & 0.6852 & -0.0341 \\
\hline D(LnEXTASS(-3)) & 0.4338 & 0.0163 & 0.0126 & 0.1728 & -0.5627 & 0.6401 & 1.1813 \\
\hline D(LnNRIDEP(-1)) & -0.1252 & 0.0469 & $0.0171 * *$ & -0.1954 & $1.14 \mathrm{E}-05$ & $-0.576^{* * *}$ & -0.1527 \\
\hline D(LnNRIDEP(-2)) & -0.0023 & 0.2411 & 0.0155 & 0.2295 & -0.0301 & 0.0402 & -0.6325 \\
\hline D(LnNRIDEP(-3)) & 0.1554 & 0.0238 & 0.0115 & -0.0304 & 0.1254 & 0.3062 & -0.2981 \\
\hline D(LnOTHERCAP(-1)) & 0.0243 & 0.0259 & $0.0077 * *$ & $0.2064 *$ & $-0.0969 * *$ & 0.0480 & $-0.3542 *$ \\
\hline D(LnOTHERCAP(-2)) & -0.0808 & 0.1750 & $0.0109 * * *$ & 0.1408 & -0.0421 & 0.0498 & -0.1128 \\
\hline D(LnOTHERCAP(-3)) & -0.0287 & 0.0800 & $0.0070 * *$ & 0.0902 & -0.0057 & 0.0263 & -0.2432 \\
\hline R-squared & 0.5885 & 0.4287 & 0.9865 & 0.6617 & 0.9228 & 0.6596 & 0.6886 \\
\hline F-statistic & 1.7709 & 0.9292 & 90.911 & 2.4220 & 14.805 & 2.3998 & 2.7378 \\
\hline
\end{tabular}

' $D$ ' represents difference form.

$* * *, * *$ and $*$ denote significance at $1 \%, 5 \%$ and $10 \%$ levels respectively.

FDI stimulates growth possibly through the transfer of technology, increasing R\&D and an improvement of human capital. The Foreign Portfolio Investment resulting from liberalization is supposed to stimulate economic growth since it boosts the supply of capital. A developing country like India needs a consistent supply of capital and its proper allocation to improve market efficiency and market microstructure. According 
to Evans (2003), well functioning equity markets also facilitate takeovers, a point where portfolio and direct investment overlap. Takeovers can turn a poorly functioning firm into an efficient and more profitable firm, and may result in strengthening the firm's performance, the financial return to its investors, and the domestic economy. Therefore, foreign portfolio investment leads to a better allocation of capital and resources in the domestic economy, and thus to a healthier economy that may stimulate growth. The contribution of foreign portfolio investment to strengthening domestic capital markets and their infrastructure, which enhances the domestic allocation of capital, can help to boost the benefits of foreign direct investment. Therefore, the two are also complementary in the sense that their benefits are enhanced when both are present.

External assistance can help key economic reforms take root in developing countries, with recipient governments and their people broadly supporting the need for change. The external assistance given to India along with strong macroeconomic fundamentals and reforms in the economic sectors has contributed towards economic growth.

NRI Deposits or Inward Remittances that have the potential to raise aggregate demand and inward remittances leading to economic growth have been significant for India. Remittance transfers promote access to financial services for the sender and the recipient. An essential aspect of leveraging remittances to promote economic development through increasing financial and social inclusion has been very important for a vast country like India. The use of remittances as foreign exchange (Ratha, 2005), and the role of remittances as an alternative to debt have helped alleviate the credit constraints of individuals in countries like India where micro-financing is not widely available (Giuliano and Ruiz-Arranz, 2006). Furthermore, strong remittance flows have helped India improve her sovereign credit rating which is important in attracting foreign capital (World Bank, 2006).

The external debt for India rises with the increase in external commercial borrowing. India is constrained to match this rise in external debt with a growth of foreign exchange reserves in the country in order to maintain her solvency. An increase in ECB is generally accompanied with the increase in currency risk resulting from a depreciation of domestic currency leading to the increased burden on the borrower at the time of repayment (Hameed et al., 2008). Also, debt overhang theories suggest that with increase in ECBs, the economy may face a debt-servicing requirement beyond its repayment capacity; thus it may lower growth through channels of poor macroeconomic policy environment and reduced investment (Krugman, 1988). Therefore the increase in ECBs is less favorable from India's point of view.

\section{Causality Test with VECM}

The results of the Causality Test with VECM are detailed in Table 5. Bi-directional causality is observed between FDI and economic growth, external assistance and economic growth and external assistance and other capital. Unidirectional causality is observed from FPI and other capital to economic growth, economic growth to NRI deposit, external assistance to FDI and from FPI to external commercial borrowing. The results related to the relationship between capital inflows and economic growth 
are consistent with the earlier tests.

Table 5

Summary of VEC Granger Causality Test

\begin{tabular}{l|l}
\hline Independent Variable & Direction of Causality \\
\hline LnFDI & DLnFDI $\leftrightharpoons$ DLnGDP \\
\hline LnFPI & $\begin{array}{l}\text { DLnFPI } \rightarrow \text { DLnGDP } \\
\text { DLnFPI } \rightarrow \text { DLnEXTCOMM }\end{array}$ \\
\hline LnEXTASS & $\begin{array}{l}\text { DLnEXTASS } \leftrightharpoons \text { DLnGDP } \\
\text { DLnEXTASS } \rightarrow \text { DLnFDI }\end{array}$ \\
\hline LnGDP & DLnGDP $\rightarrow$ DLnNRIDEP \\
\hline LnOTHERCAP & $\begin{array}{l}\text { DLnOTHERCAP } \rightarrow \text { DLnGDP } \\
\text { DLnOTHERCAP } \rightarrow \text { DLnEXTASS }\end{array}$ \\
\hline LnEXTCOMM & DLnEXTCOMM $\rightarrow$ DLnEXTASS \\
\hline
\end{tabular}

Impulse Response Analysis

We have observed from the cointegration test that the variables are in a long run relationship. Therefore it is important to know the response of economic growth in each time period when each of the components of capital flows receives a unit shock, and also to know the response of each of the components when economic growth receives that shock. The Impulse response figures show how a shock to any one of the seven variables considered in the study affects all the other variables in the system. We also verify that the response is statistically significant. Technically, the shocks are orthogonalized by using the Choleski decomposition method. The Impulse Response Analysis is done by estimating the VAR at first difference of the variables, and the optimal lag length is chosen to be 3 (minimum of AIC or SBIC or HQIC or FPE value). We presented the IR estimates only for the variables that appear to significantly Granger cause other variables (based on the Causality Test). The IR function for the VAR system is calculated in the order of FDI, FPI, GDP, EXTCOMM, EXTASS, NRIDEP, OTHERCAP and is illustrated in Figures 2(a) to 2(g). The figures show that the directions of relationship indicated by causality analysis are maintained and they are statistically significant. The results of the impulse response functions are consistent with the t-statistics for differences of the variables in estimated co-efficients. 
Figure 2(a)

Impulse Response of D(LnFDI) to One-standard Deviation Shocks in Other Variables

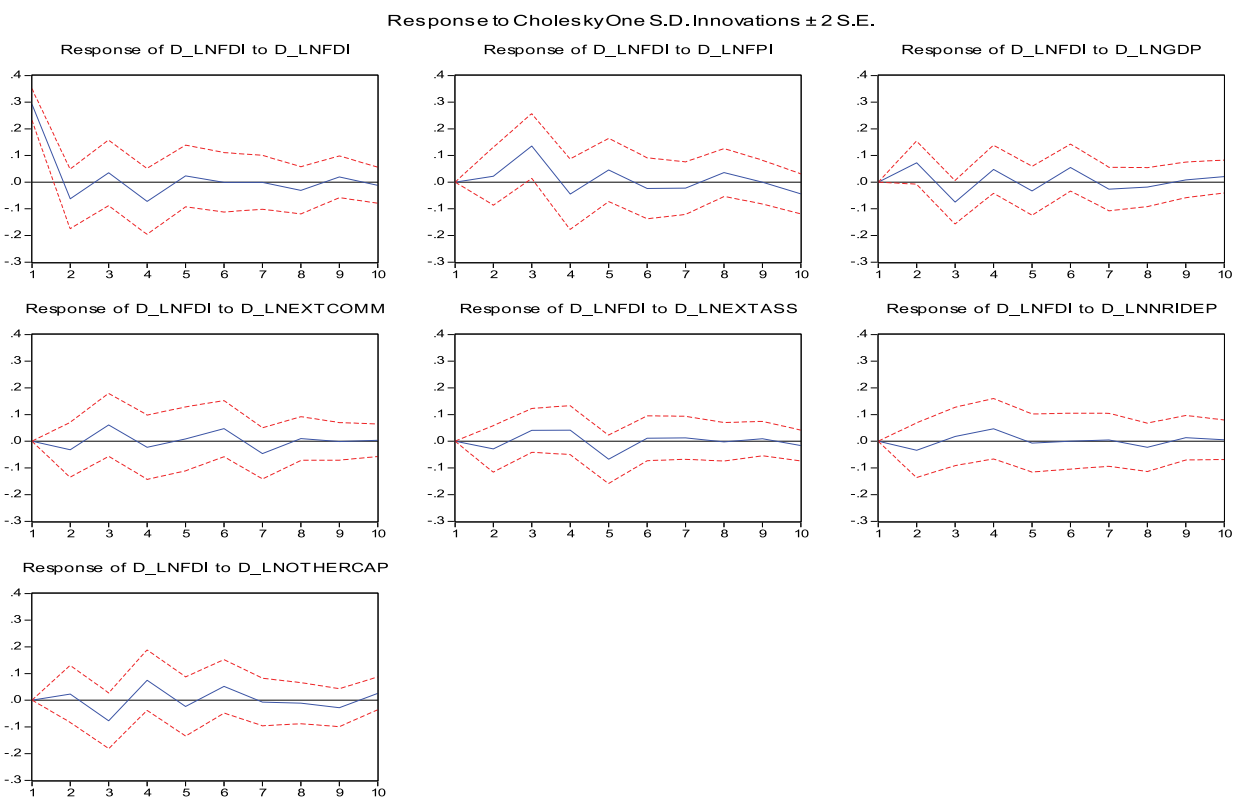

Figure 2(b)

Impulse Response of D(LnFPI) to One-standard Deviation Shocks in Other Variables

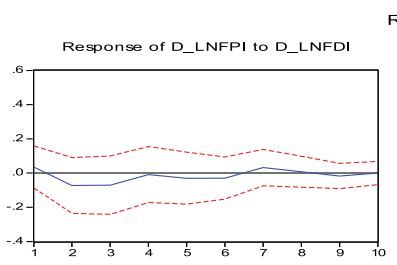
Response to CholeskyOne S.D. Innovations \pm 2 S.E.
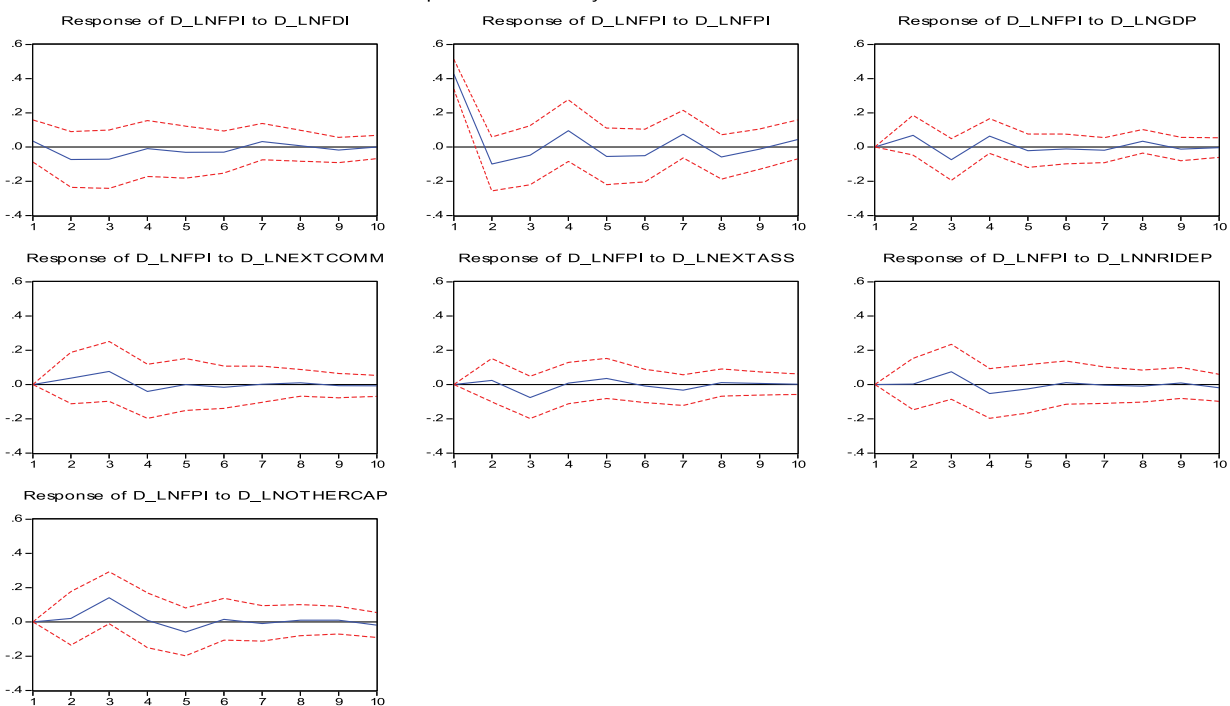
Figure 2(c)

Impulse Response of D(LnGDP) to One-standard Deviation Shocks in Other Variables
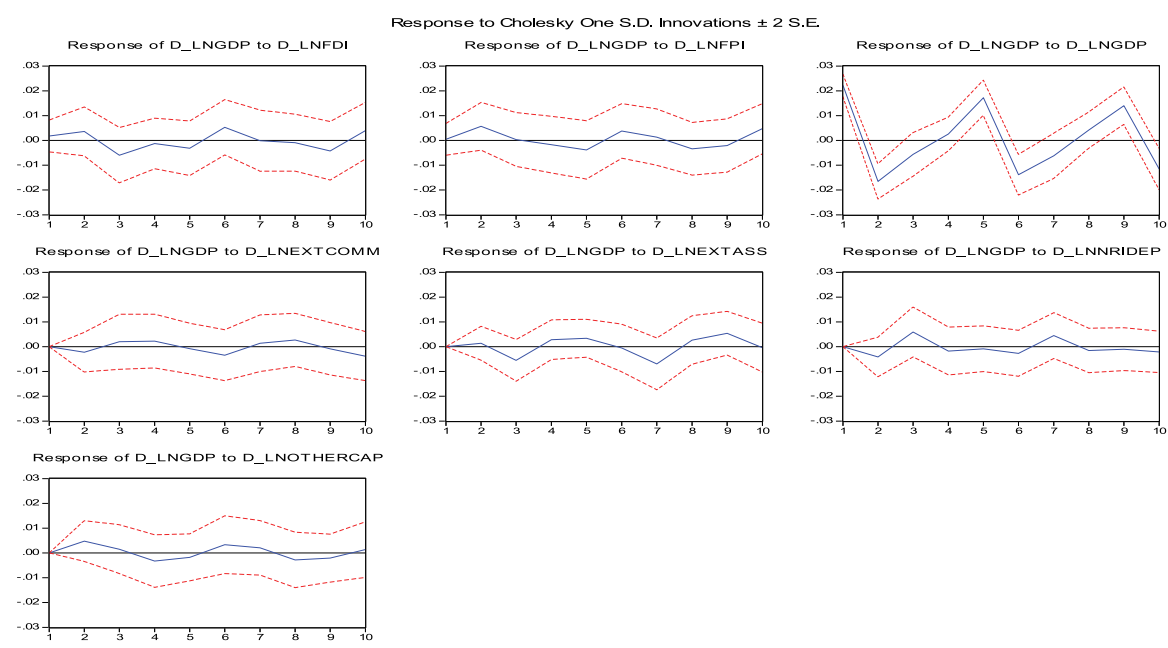

Figure 2(d)

Impulse Response of D(LnEXTCOMM) to One-standard Deviation Shocks in Other Variables

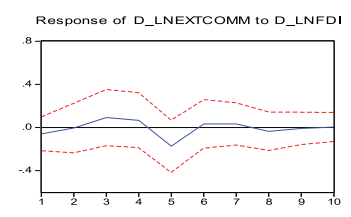

Response of D_LNEXTCOMM to D_LNEXTCOMM

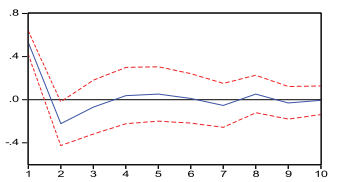

Response of D_LNEXTCOMM to D_LNOTHERCAP

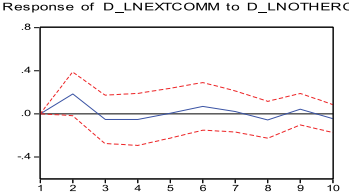

Response to Cholesky One S.D. Innovations \pm 2 S.E

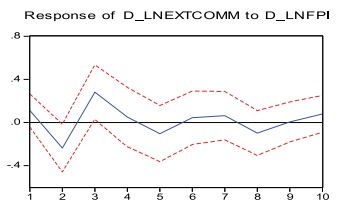

Response of D_LNEXTCOMM to D_LNEXTASS

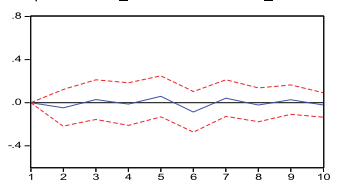

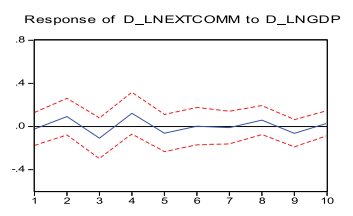

Response of D_LNEXTCOMM to D_LNNRIDEP

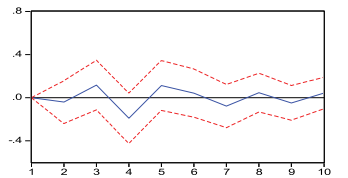


Figure 2(e)

Impulse Response of D(LnEXTASS) to One-standard Deviation Shocks in Other Variables

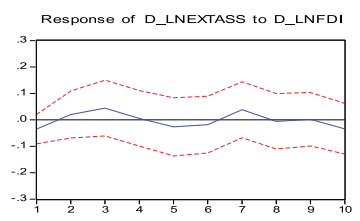

Response to Cholesky One S.D. Innovations \pm 2 S.E

Response of D_LNEXTASS to D_LNEXTCOMM
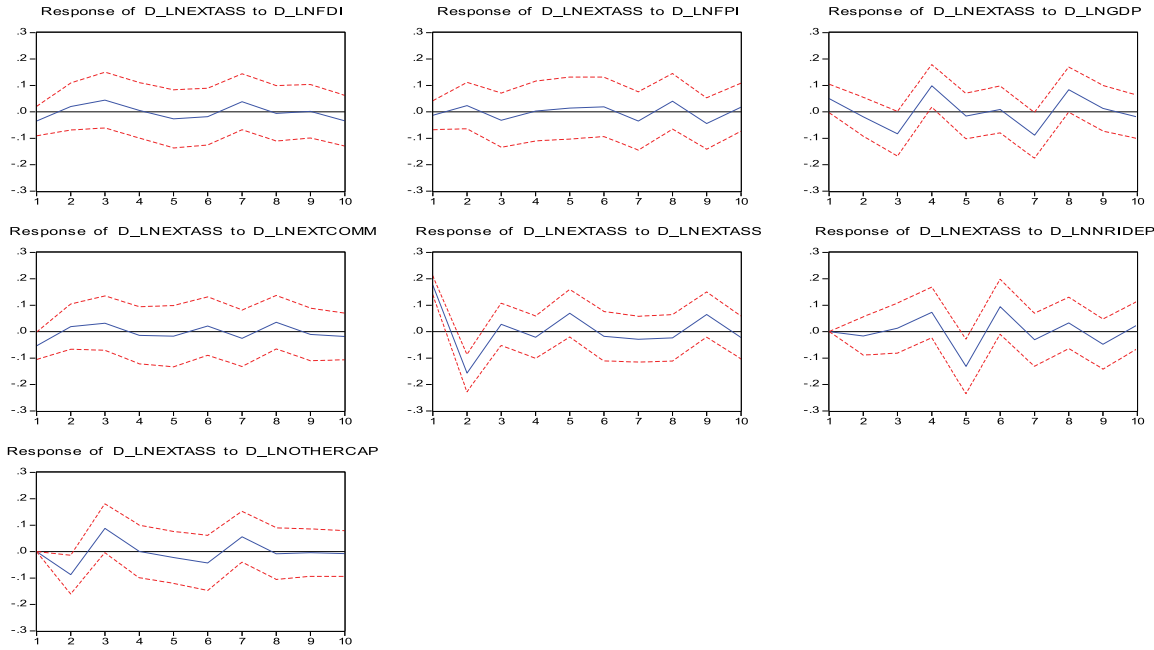

Figure 2(f)

Impulse Response of D(LnNRIDEP) to One-standard Deviation Shocks in Other Variables

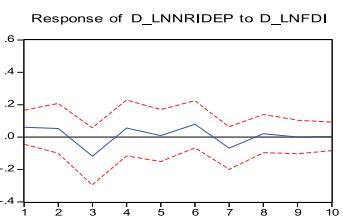

Response to Cholesky One S.D. Innovations \pm 2 S.E

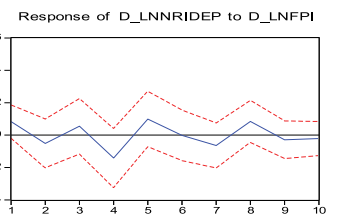

Response of D_LNNRIDEP to D_LNGDP

Response of D_LNNRIDEP to D_LNEXTCOMM

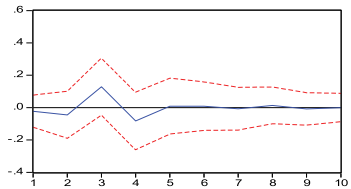

Response of D_LNNRIDEP to D_LNEXTASS
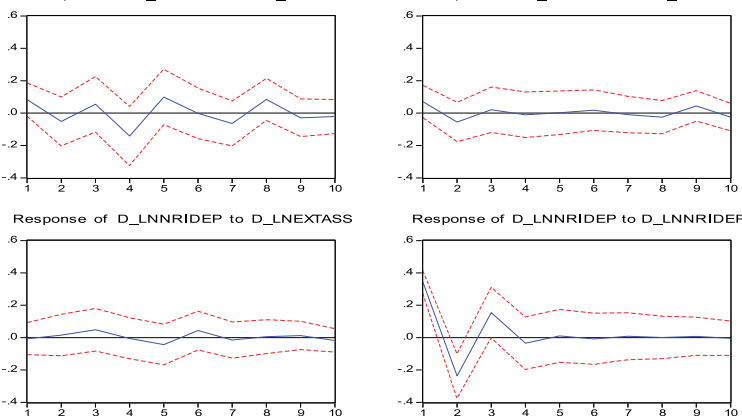

Response of D_LNNRIDEP to D_LNNRIDEP

Response of D_LNNRIDEP to D_LNOTHERCAP
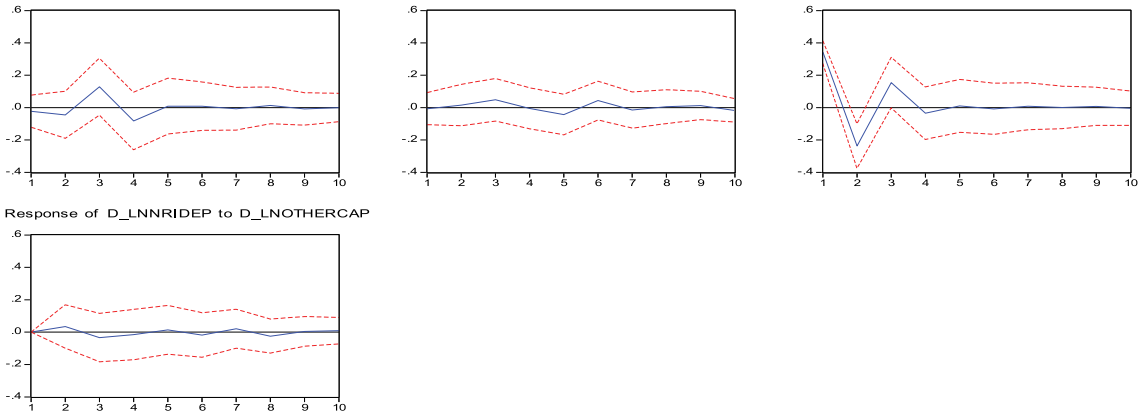
Figure 2(g)

Impulse response of D(LnOTHERCAP) to One-standard Deviation Shocks in Other Variables

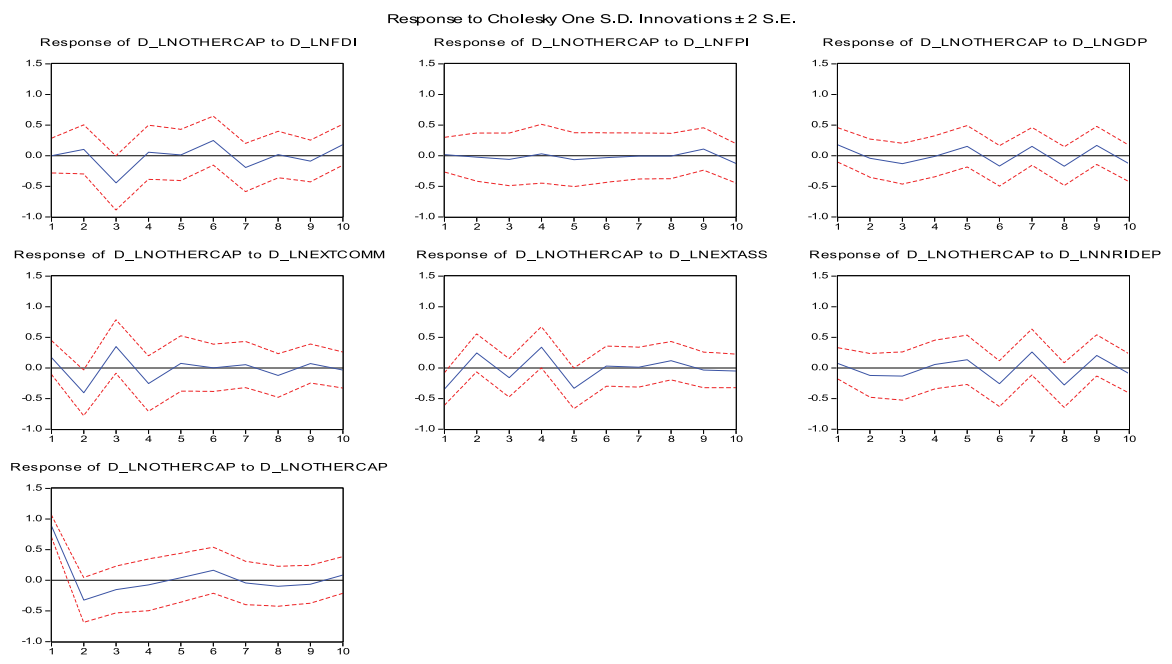

\section{Conclusion}

After financial sector reforms led to the gradual liberalization of the Indian economy, it was thought that capital inflows would contribute towards India's economic growth. The results of the study suggest that capital inflows have contributed towards that growth. All the variables are in a long term relationship although we cannot tell the directions of such relationship because such directions are not revealed by a cointegration analysis. Using VECM we observe that changes in GDP can be explained by the group of explanatory factors in the long run and the directions of relationship between the GDP and each of the explanatory variables in the short run. We find that the rises in FDI, FPI, NRIDEP, EXTASS and OTHERCAP have a positive impact on GDP in the short run, but the higher EXTCOMM has a negative impact on GDP in the short run. The findings from the causality analysis suggest that economic growth in India has also contributed towards capital flows such as foreign direct investment and external assistance. In principle, by bringing in capital, technology and knowhow, managerial skills, international marketing networks, and other assets, FDI can create jobs and stimulate growth. In line with Kose et al. (2006), we argue that other non-FDI flows stimulate growth by providing certain 'collateral benefits' including financial market and institutional development, better governance, improved demand and macroeconomic discipline. Consistent with other empirical studies and as observed by Bussiere and Fratzscher, (2008) and discussed earlier, our estimates give more prominent relationships in short run relationships but also provide evidence of the long term relationship among the variables using the cointegration test. 
The previous studies in the Indian context have either tested the FDI-led growth hypothesis or have used generic aggregate capital flows data. We have not come across any study in the Indian context that examined the relationship between individual components of capital flows and economic growth. Our overall results are in line with the earlier studies by Pradhan (2010) and Ray (2012) where they reported a bi-directional relationship between FDI and economic growth. The findings are consistent with studies by Duttaray et al. (2003) where the authors observed that the capital-growth relationship is an aspect of two-way causality relationships. However, our findings contradict the findings of Mazumdar (2005) where the author suggested that capital inflows have not contributed towards either industrial production or economic growth, and noted that either the amount of capital inflows had not been enough or the amounts flowing in had not been properly utilized. Unlike Mazumdar (2005), we have used individual components of capital flow and separately tested their impact on growth. We argue that during our study period, particularly during 2005-2007, Indian stock markets were climbing newer heights and India witnessed an increased FII participation in financial markets which led to a huge surge in FPI. India has not only been among the top five remittances receiving countries for the last few years, remittances inflow also have had an annual average growth trend of 16 percent during the period of 1990-2008, with 34 percent growth in 2008 (UNCTAD, 2011). These capital flows have contributed to the economic growth which was not found by Mazumdar (2005).

\section{Implications for India}

With non-debt creating flows positively affecting economic growth, the challenge before India is to ensure continuing capital flows into the economy and their subsequent absorption. On the policy front, it is important for the Indian government to maintain an environment that attracts FDI and FPI and at the same time ensures a steady flow of inward remittances. In the recent period, the strong capital flows reflect the sustained impetus in domestic economic activity, enhanced corporate performance, a positive investment climate and the long term view of India as an investment destination. However India needs to be cautious since large capital inflows that are in excess of a sustained current account deficit are a stress on the real economy. Pressures on exchange rate appreciation and sterilization would lead to a widening of the trade deficit and possibly to a slowdown in economic and industrial growth. Therefore the challenges for monetary and exchange rate management in India are the high capital inflows along with the low domestic absorption capacity of the economy. However it is argued that development and maturation of the financial market would mitigate the challenge of capital flows in the short to medium term. The findings of our study support the thrust of policy reforms in India which is in favor of a compositional shift in capital flows away from debt- to non-debt creating flows. This then supports the policy of the FDI and FPI, the strict regulation of external commercial borrowings and especially short-term debt, the discouragement of the volatile element of flows from NRI's, a gradual liberalization of outflows and a disintermediation of the government in the flow of external assistance. A proper management of the capital account is critical for the growth and stability of 
a country like India. There is need of a sound and stable monetary and fiscal policy, a phased liberalization of the policy framework in relation to current as well as capital account outflows, a lowering of interest rate ceilings on NRI deposits, a foreign exchange market intervention and a subsequent sterilization along with, a more flexible exchange rate regime appropriate to an environment of open capital markets.

The massive injections of liquidity by central banks in advanced economies along with the strong fundamentals of the Indian economy are expected to lead to sustained capital inflows for the Indian economy. If the pressure regarding the conduct of monetary policy and liquidity management intensifies it may necessitate stepped-up operations in terms of capital account management and more active liquidity management by the Reserve Bank of India. It is necessary in the context of recent global events not to exclude the possibility of reversals of capital flows due to abrupt changes in sentiment or global liquidity conditions. It is indeed a challenge for an emerging market economy like India to see that the benefits of capital flows exceed their costs.

\section{References}

Blomstrong, M., Lipsey, R.E., and Zegan, M. (1992). "What Explains Developing Country Growth?" NBER Working Paper no. 4132.

Borensztein, E., Gregorio, J.D., and Lee, J.W. (1998). "How Does Foreign Direct Investment Affect Economic Growth?” Journal of International Economics, 45(1): 115-135.

Bosworth, B. and Collins, S.M. (1999). "Capital Flows to Developing Economies Implications for Savings and Investments," Brookings Papers on Economic Activity, 1: 143-169.

Bussière, M. and Fratzscher, M. (2008). "Financial Openness and Growth: Short-run Gain, Long-run Pain?" Review of International Economics, 16(1): 69-95.

Carkovic, M. and Levine, R. (2002). "Does Foreign Direct Investment Accelerate Economic Growth?" University of Minnesota Department of Finance Working paper, June.

Chami, R., Fullenkamp, C., and Jahjah, S. (2003). "Are Immigrant Remittance Flows a Source of Capital for Development?” IMF Working Paper 01/189, International Monetary Fund, Washington DC.

Dickey, D.A. and Fuller, W.A. (1979). "Distribution of the Estimations for Autoregressive Time Series with a Unit Root," Journal of American Statistical Association, 74(366): 427-431.

Dickey, D.A., Jansen, D.W., and Fuller, W.A. (1991). “A Primer on Cointegration with an Application to Money and Income," Review Federal Reserve Bank of St. Louis, 73: 58-78.

D’Souza, E. (2008). "Globalisation's Underbelly: Capital Flows and Indian Economy," Economic and Political Weekly, XLIII(35): 34-39.

Duttaray, M., Dutt A.K., and Mukhopadhyay, K. (2003). "The Relation Between Foreign Direct Investment and Growth: Causality and Mechanisms," Asian Development Review, 83: 369-375.

Engle, R.F. and Granger, C.W.J. (1987). "Cointegration and Error-Correction: Representation, Estimation, and Testing," Econometrica, 55(2): 251-276.

Evans, K. (2003). "Foreign Portfolio and Direct Investment: Complementarity, Differences, and Integration" in Proceedings of the OECD Global Forum on International Investment: Attracting International Investment for Development, Shanghai. 
Faini, R. (2002). "Development, Trade, and Migration,” Revue d'Économie et du Développement, Proceedings from the ABCDE Europe Conference, 1-2: 85-116.

Gounder, R. and Xayavong, V. (2001). "Globalization and the Island Economies of the South Pacific," United Nations University World Institute for Development Economies Research (UNUWIDER) Discussion papers no.2001/41, New Zealand.

Grossman, G.M. and Helpman, E. (1991). "Innovation and Growth in Global Economy," Cambridge: MIT Press.

Giuliano, P. and Ruiz-Arranz, M. (2006). "Remittances, Financial Development, and Growth," IMF Working Paper No. 05/234, Washington D.C.

Hameed , A., Ashraf, H., and Chaudhary, M. (2008). "External Debt and Its Impact on Economic and Business Growth in Pakistan," International Research Journal of Finance and Economics, 20: 132-140.

Howitt, P. and Aghion, P. (1998). "Capital Accumulation and Innovation as Complementary Factors in Long-Run Growth," Journal of Economic Growth, 3(2): 111-130.

Howitt, P. (2000). "Endogenous Growth Theory and Cross Country Differences," American Economic Review, 90(4): 829-846.

Hendry, D.F. and Mizon, G.E. (1993). "Evaluating Dynamic Econometric Models by Encompassing the VAR," in P.C.B. Phillips (ed.), Models, Methods and Applications of Econometrics: 272-300. Oxford: Basil Blackwell.

Johansen, S. (1988). "Statistical Analysis of Co-integrating Vectors," Journal of Economic Dynamics and Control, 12(6): 231-254.

Johansen, S. and Juselius, K. (1990). "Maximum Likelihood Estimation and Inference on Cointegration with Application to the Demand for Money," Oxford Bulletin of Economics and Statistics, 52(2): 169-210.

Kohli, R. (2001). "Capital Flows and Their Macro Economic Effects in India," Working Paper ICRIER, 64: 11-42.

-----, (2003). “Capital Flows and Domestic Financial Sector in India,” Economic Political Weekly, 38(8): 761-768.

Kose, M.A., Prasad, E., Rogoff, K., and Wei, S.J. (2006). "Financial Globalization: A Reappraisal," IMF Working Paper 06/189. Washington, DC: International Monetary Fund.

Krugman P. (1988). "Financing versus Forgiving a Debt Overhang," Journal of Development Economics, 29(3): 253-268.

Kwiatkowski, D., Phillips, P.C.B., Schmidt, P. and Shin, Y. (1992). "Testing the Null Hypothesis of Stationarity against the Alternative of a Unit Root," Journal of Econometrics, 54 (1/3): 159-178.

Lucas, R. (1988). "On the Mechanics of Economic Development," Journal of Monetary Economics, 22(1): 3-42.

MacKinnon, J.G., Haug, A.A., and Michelis, L. (1999). "Numerical Distribution Functions of Likelihood Ratio Tests for Cointegration," Journal of Applied Econometrics, 14(5): 563-577.

Mazumdar, T. (2005). "Capital Flows into India: Implications for Its Economic Growth," Economic and Political Weekly, 40(21): 2183-2189.

McKinnon, R. and Pill. H. (1997). "Credible Economic Liberalizations and Overborrowing," American Economic Review, 87(2): 189-93. 
, (1999). "Exchange-Rate Regimes for Emerging Markets: Moral Hazard and International Overborrowing," Oxford Review of Economic Policy, 15(3): 19-39.

Phillips, P.C.B. and Perron, P. (1988). “Testing for a Unit Root in Time Series Regression,” Biometrika, 75(2): 335-346.

Pradhan, R.P. (2010). "Financial Deepening, Foreign Direct Investment and Economic Growth: Are They Cointegrated," International Journal of Financial Research, 1(1): 37-43.

Prasad E.S., Rajan R.G., and Subramanian, A. (2007). "Foreign Capital and Economic Growth," NBER Working Paper No.13619.

Rangarajan, C. (2000). "Capital Flows: Another Look," Economic and Political Weekly, 35(50): 4421-4427.

Ratha, D. (2005). "Remittances: A Lifeline for Development," Finance and Development, 42(4): 42-45.

Ray, S. (2012). "Impact of Foreign Direct Investment on Economic Growth in India: A Cointegration Analysis," Advances in Information Technology and Management, 2(1): 187-201.

Romer, P. (1990). “Endogenous Technological Change,” Journal of Political Economy, 98(5): 71-102.

Romer, P. M. and Rivera, L. A. (1990). "Economic Integration and Endogenous Growth,” NBER Working Paper No. 3528.

Spatafora, N. (2005). "Worker's Remittances and Economic Development," (Chapter 2) in World Economic Outlook: Globalization and External Imbalances. Washington, DC: International Monetary Fund.

Solow, R. (1992). "Policies for Economic Growth," De Economist, 140(1): 1-15.

Thomas, A. (1993). "The Influence of Wages and House Price Decisions on British Interregional Migration," Applied Economics, 25(9): 1261-1268.

UNCTAD (2011). "Impact of Remittances on Poverty in Developing Countries," UNCTAD/United Kingdom Department for International Development/Government of India Project on 'Strategies and Preparedness for Trade and Globalization in India," Geneva, 1-40.

World Bank (2001). Global Development Finance. Washington DC.

------, (2006). Global Economic Prospects. Washington DC. 